\title{
Thermal Inactivation of Sodium-Habituated Staphylococcus aureus in Ready-to-Heat Sauces
}

\author{
Ahreum Park, Jinhee Lee, Sook-Jin Jeong ${ }^{1}$, In-Gyun Hwang ${ }^{1}$, Soon-Ho Lee ${ }^{1}$, Joon-II Cho', and Yohan Yoon* \\ Department of Food and Nutrition, Sookmyung Women's University, Seoul 140-742, Korea \\ ${ }^{I}$ Food Microbiology Division, Food Safety Evaluation Department, National Institute of Food and Drug Safety Evaluation, \\ Korea Food \& Drug Administration, Osong 363-700, Korea
}

\begin{abstract}
The objective of this study was to evaluate the effect of sodium habituation on thermal resistance of Staphylococcus aureus in various ready-to-heat (RTH) sauces. The strain mixture of S. aureus strains KACC10768, KACC10778, KACC11596, KACC13236 and NCCP10862 was habituated up to $9 \%$ of NaCl. The inocula of NaCl-habituated and nonhabituated $S$. aureus were inoculated in $5 \mathrm{~g}$ portions of pork cutlet, meat and Carbonara sauces at $7 \mathrm{Log}$ CFU/g, and the samples were vortexed vigorously. The inoculated samples were then exposed to 60 and $70^{\circ} \mathrm{C}$ in a water-bath, and survivals of total bacteria and $S$. aureus were enumerated on tryptic soy agar and mannitol salt agar, respectively, every 30 min for $120 \mathrm{~min}$. At $60^{\circ} \mathrm{C}$, the cell counts of total bacteria and the significant difference in survivals between sodium-habituated and non-habituated $S$. aureus were observed only in the Carbonara sauce; the tailing effect, which is the period of no reduction of bacterial cell counts, was observed in pork cutlet, meat and Carbonara sauces subjected to $60^{\circ} \mathrm{C}$. At $70^{\circ} \mathrm{C}$, total bacterial populations and sodium-habituated and non-habituated $S$. aureus cell counts in meat and Carbonara sauce also significantly decreased $(p<0.05)$ after $30 \mathrm{~min}$ of heat treatment, followed by the obvious tailing effect. Sodium-habituated $S$. aureus cell counts in meat and Carbonara sauces were higher $(p<0.05)$ than those of non-habituated $S$. aureus at $70^{\circ} \mathrm{C}$. The results indicate that sodium habituation of $S$. aureus cells may increase the thermal resistance of the pathogen in RTH sauces; moreover, heating RTH sauces for a short time before serving may not sufficiently decrease the cell counts of $S$. aureus, particularly for sodium-habituated strain.
\end{abstract}

Key words: Staphylococcus aureus, ready-to-heat sauces, thermal inactivation, NaCl-habituation

\section{Introduction}

Staphylococcus aureus has been related to the foodborne disease in various foods, such as pork, chicken and ready-to-eat (RTE) salad in the United States (CDC, 2012). The pathogen grows in foods and produces enterotoxins, and $S$. aureus also is heat stable bacteria in cooking process (Bang et al., 2008). In addition, the pathogen is a major cause of bacteremia, and it is closely related to higher mortality and morbidity, compared to the bacteremia caused by other pathogens (Naber, 2009). Since lifestyle has been changed, convenient foods such as RTE and ready-to-heat $(\mathrm{RTH})$ foods have become popular. Because of this consumption pattern in the United States

\footnotetext{
*Corresponding author: Yohan Yoon, Department of Food and Nutrition, Sookmyung Women's University, Seoul 140-742, Korea. Tel: +82-2-2077-7585; Fax: +82-2-710-9479; E-mail: yyoon@sookmyung.ac.kr
}

968 cases of foodborne disease were caused by fast foods in 2010 (CDC, 2012). Especially, there were 55 reported outbreaks with 1,875 cases caused by various sauces in the United States from 1990 to 2003 (Dewaal et al., 2006).

Optimum growth conditions for $S$. aureus are at 35$41^{\circ} \mathrm{C}$ of growth temperature, 6-7 of $\mathrm{pH}, 0.990$ of $\mathrm{a}_{\mathrm{w}}$, and $0 \%$ of $\mathrm{NaCl}$ (Schelin et al., 2011). However, S. aureus can grow even at $\mathrm{pH} 4.2$ and up to $15 \%$ of $\mathrm{NaCl}$, which is the condition found in various sauces (Ingham et al., 2005; USDHHS/FDA, 2011).

When foodborne pathogenic bacteria are exposed to sublethal stresses such as acid, heat, salt and various preservatives, the pathogen may become more tolerant to the subsequent other stresses called cross-protection or crossresistance response (Archer, 1996; Beales, 2004; Hill et al., 2002). Moreover, continuous exposure of pathogenic bacteria to sublethal stresses may also increase the resistance of bacteria to the same or other stresses (Koutsoumanis et al., 2003). For instance, the acid (pH 3.5) chal- 
lenge, followed by osmotic treatment $\left(\mathrm{a}_{\mathrm{w}} 0.9\right)$ at $25^{\circ} \mathrm{C}$ increased Escherichia coli stress tolerance than the reverse order exposure (Shadbolt et al., 2001). In a case of Listeria monocytogenes the pathogen of heat shock at $45^{\circ} \mathrm{C}$ for $1 \mathrm{~h}$ increased the tolerance to $\mathrm{NaCl}(25 \%)$, crystal violet $(0.01 \%)$, and ethanol (18\%) (Lin and Chou, 2004). Exposure of $S$. aureus to heat, hydrogen peroxide, and alkaline media also developed homologous stress responses of the pathogen (Cebrian et al., 2010). Thus, exposure of $S$. aureus to sodium in food-related conditions may increase thermal resistance of the bacteria by habituation.

Therefore, the objective of this study was to evaluate if sodium habituation of $S$. aureus in various foods increases its thermal resistance in various RTH sauces.

\section{Materials and Methods}

\section{Habituation of $\boldsymbol{S}$. aureus to sodium}

The isolated colonies of $S$. aureus strains (KACC10768, KACC10778, KACC11596, KACC13236 and NCCP10862) on mannitol salt agar (MSA; Difco ${ }^{\mathrm{TM}}$, Becton Dickinson and Company, USA) were cultured in brain heart infusion broth (BHI; Difco ${ }^{\mathrm{TM}}$ ) at $35^{\circ} \mathrm{C}$ for $24 \mathrm{~h}$. The $0.1 \mathrm{~mL}$ of the culture was then transferred into $10 \mathrm{~mL}$ of BHI broth for subculture at $35^{\circ} \mathrm{C}$ for $24 \mathrm{~h}$. To habituate $S$. aureus to sodium, $0.1 \mathrm{~mL}$ of the culture was inoculated in $10 \mathrm{~mL}$ of BHI broth supplemented with $3 \% \mathrm{NaCl}$, following incubation at $35^{\circ} \mathrm{C}$ for $24 \mathrm{~h}$, and $0.1 \mathrm{~mL}$ of the culture was transferred to $10 \mathrm{~mL}$ BHI broth supplemented with $6 \%$ $\mathrm{NaCl}$ and the culture was incubated at $35^{\circ} \mathrm{C}$ for $24 \mathrm{~h}$. Eventually, $0.1 \mathrm{~mL}$ of this culture was transferred to 10 $\mathrm{mL}$ of $\mathrm{BHI}$ broth supplemented with $9 \%$ of $\mathrm{NaCl}$, which could be found in fermented sea foods (Kim et al., 2006). It was then incubated at $35^{\circ} \mathrm{C}$ for $24 \mathrm{~h}$.

Non-habituated $S$. aureus was prepared by consecutive incubation only in BHI broth. The $10 \mathrm{~mL}$ of sodiumhabituated and non-habituated $S$. aureus were centrifuged at $1,912 \mathrm{~g}$ and $4^{\circ} \mathrm{C}$ for $15 \mathrm{~min}$. The supernatants were then discarded, and the cell pellets were washed twice with phosphate buffered saline (PBS, $\mathrm{pH} 7.4 ; 0.2 \mathrm{~g}$ of $\mathrm{KH}_{2} \mathrm{PO}_{4}, 1.5 \mathrm{~g}$ of $\mathrm{Na}_{2} \mathrm{HPO}_{4} \cdot 7 \mathrm{H}_{2} \mathrm{O}, 8.0 \mathrm{~g}$ of $\mathrm{NaCl}$, and 0.2 $\mathrm{g}$ of $\mathrm{KCl}$ in $1 \mathrm{~L}$ of distilled water), and the pellets were resuspended in PBS to prepare sodium-habituated and non-habituated $S$. aureus inocula at 8-9 Log CFU/mL.

\section{Inoculation and heat challenge}

Pork cutlet, meat, and Carbonara sauces were purchased from a local grocery store. Five gram portions of each sauce were transferred into tubes, and the sauce samples were immersed in a water bath until internal temperatures of the sauce samples reached at 60 and $70^{\circ} \mathrm{C}$. The $0.1 \mathrm{~mL}$ portions of the inocula were inoculated into the sauce samples at 6-7 Log $\mathrm{CFU} / \mathrm{g}$, and the samples were immersed again in a water bath at 60 and $70^{\circ} \mathrm{C}$ after vortexing samples. The samples were microbiologically analyzed at $0,30,60,90$, and $120 \mathrm{~min}$.

\section{Microbiological analysis}

To enumerate survivals of total bacteria and $S$. aureus, $5 \mathrm{~mL}$ of $0.1 \%$ buffered peptone water (BPW, Difco ${ }^{\mathrm{TM}}$ ) was added to the samples followed by vortexing, and each sample was then transferred to a filter bag (BagFilter $^{\circledR}$, Interscience, France). The samples were pummeled for $30 \mathrm{~s}$ by a pummeler $\left(\right.$ BagMixer $\left.^{\circledR}\right)$ and serially diluted with BPW. The $0.1 \mathrm{~mL}$ portions of the diluents were spread-plated on tryptic soy agar (TSA; Difco ${ }^{\mathrm{TM}}$ ) and MSA for total bacteria and $S$. aureus, respectively. The agar plates were incubated at $35^{\circ} \mathrm{C}$ for $24 \mathrm{~h}$, and colonies were manually counted.

\section{Statistical analysis}

The experiment was repeated twice with two samples per repeat. Microbiological data ( $\mathrm{CFU} / \mathrm{g})$ were transferred to $\mathrm{Log} \mathrm{CFU} / \mathrm{g}$, and analyzed by the mixed model procedure of SAS $^{\circledR}$ version 9.2 (SAS Institute Inc., USA). Pairwise $t$-test was used to compare least significant means of the fixed effects (heating timexinocula) to determine significant differences at alpha $=0.05$.

\section{Results and Discussion}

The heat treatment at $60^{\circ} \mathrm{C}$ significantly decreased $(p<$ $0.05)$ bacterial populations of total bacteria in pork cutlet sauce (Data not shown in a tabular form). S. aureus in the pork cutlet sauce also rapidly decreased $(p<0.05)$ by more than $5 \mathrm{Log} \mathrm{CFU} / \mathrm{g}$ after 30-min heat challenge, and then gradually decreased $(p \geq 0.05)$ to below detection limit (0.3 Log CFU/g) after heat challenge for $120 \mathrm{~min}$ (Fig. 1). Hence, the pork cutlet sauce was not further subjected to $70^{\circ} \mathrm{C}$ and sodium-habituated strain was not tested for the sauce.

For meat and Carbonara sauces, total bacterial populations decreased $(p<0.05)$ by 1.5-3.2 Log CFU/g (Data not shown in a tabular form). $S$. aureus also significantly decreased $(p<0.05)$ to $1.9-3.5 \mathrm{Log} \mathrm{CFU} / \mathrm{g}$ during heat challenge at $60^{\circ} \mathrm{C}$ for $120 \mathrm{~min}$, regardless of sodiumhabituation (Fig. 2). There was no difference in $S$. aureus cell counts between sodium-habituated and non-habitu- 


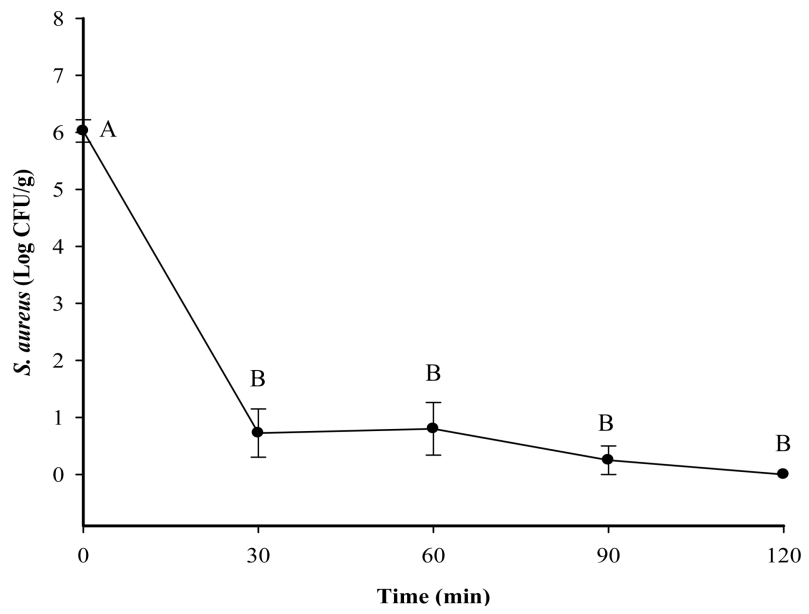

Fig. 1. Survival of Staphylococcus aureus in pork cutlet sauce during heat challenge at $60^{\circ} \mathrm{C}$ for $120 \mathrm{~min}$. $\mathrm{A}-\mathrm{B}$, means with different letters are different $(p<0.05)$.
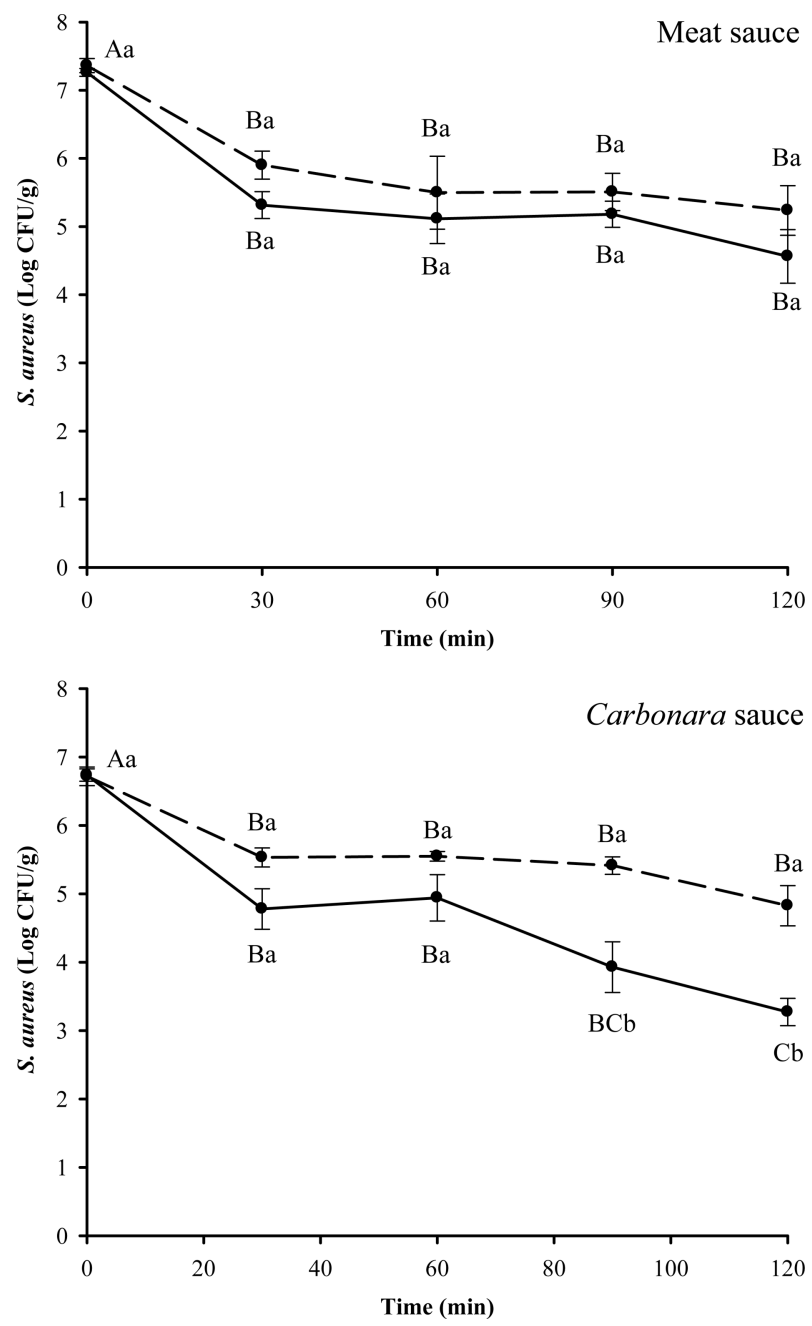

Fig. 2. Survival of sodium-habituated (dashed line) and nonhabituated (solid line) Staphylococcus aureus in meat and Carbonara sauces during heat challenge at $60^{\circ} \mathrm{C}$ for $120 \mathrm{~min}$. A-C, means within dashed line or solid line with different letters are different $(p<0.05)$; $a-b$, means within time with different letters are different $(p<0.05)$. ated $S$. aureus in meat sauce during heat challenge, but sodium-habituated $S$. aureus cell counts were higher $(p<0.05)$ than non-habituated $S$. aureus cell counts in Carbonara sauce (Fig. 2).

During heat challenge at $60^{\circ} \mathrm{C}$, more reduction of $S$. aureus cell counts was observed in pork cutlet sauce than those in meat and Carbonara sauces (Figs. 1 and 2). The combined effect of heat with lower $\mathrm{pH}$ value $(\mathrm{pH} 3.5)$ of pork cutlet sauce compared to meat $(\mathrm{pH} 4.5)$ and Carbonara sauces ( $\mathrm{pH} 5.7$ ) may cause rapid decrease of $S$. aureus cell counts to the below detection limit because low $\mathrm{pH}$ of samples may sensitize the bacterial cells than other cells to thermal stress (Yoon et al., 2011).

After 30-min heat challenge at $70^{\circ} \mathrm{C}, \mathrm{S}$. aureus populations in meat and Carbonara sauces decreased $(p<0.05)$
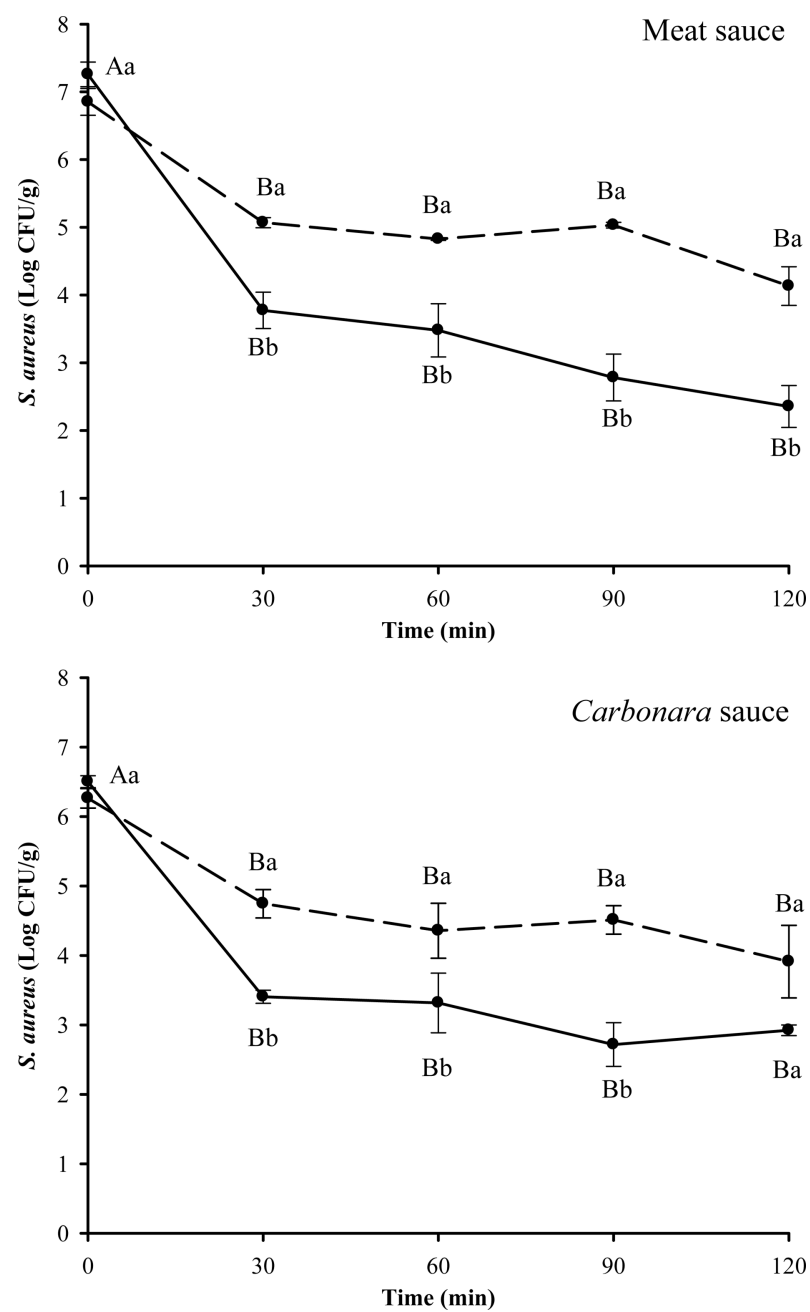

Fig. 3. Survival of sodium-habituated (dashed line) and nonhabituated (solid line) Staphylococcus aureus in meat and Carbonara sauces during heat challenge at $70^{\circ} \mathrm{C}$ for $120 \mathrm{~min}$. A-B, means within dashed line or solid line with different letters are different $(p<0.05)$; $\mathrm{a}-\mathrm{b}$, means within time with different letters are different $(p<0.05)$. 
by 1.8-3.5 Log CFU/g and 1.5-3.1 Log CFU/g, respectively, regardless of sodium habituation (Fig. 3). This result suggests that $S$. aureus contamination in RTH sauces, which are usually heated only for short time before serving, may not decrease sufficiently bacterial contamination, resulting in foodborne illness. After 30-min heat challenge, tailing effect, which is the period for no reduction of bacterial cells counts, was observed in survival curves (Fig. $3)$. There were total $S$. aureus cell count reductions of 2.7-4.9 Log CFU/g and 2.4-3.6 Log CFU/g after $120 \mathrm{~min}$ of heat challenge for meat and Carbonara sauces, respectively, which were close to the survival counts after 30min heat challenge (Fig. 3). The tailing effect in inactivation curves is attributed to a proportion of the survivals with higher stress resistance or to damage repair of injured bacterial cells on media (Chen, 2007; San Martin et al., 2002).

During heat challenge at $70^{\circ} \mathrm{C}$, sodium-habituated $S$. aureus cell counts were higher $(p<0.05)$ than those of non-habituated $S$. aureus in meat and Carbonara sauces (Fig. 3). A study by Yoon et al. (2009, 2011) showed that Escherichia coli O157:H7 had higher thermal resistance in non-intact beef formulated with $\mathrm{NaCl}$ after cooking at $65^{\circ} \mathrm{C}$. Sequential exposure of $L$. monocytogenes to sublethal stresses including sodium also increased L. monocytogenes survival under subsequent stresses (Skandamis et al., 2009). Taken together, sodium habituation of S. aureus may increase its thermal resistance in RTH sauces.

In conclusion, exposure of $S$. aureus to sodium under food-related conditions may increase its thermal resistance in RTH sauces, and short-time heating RTH sauces before serving may not decrease sufficiently cell counts of $S$. aureus, especially for sodium-habituated strain.

\section{Acknowledgement}

This research was supported by a grant (\#11162KFDA044) from Korea Food \& Drug Administration in 2011.

\section{References}

1. Archer, D. L. (1996) Preservation microbiology and safety: evidence that stress enhances virulence and triggers adaptive mutations. Trends Food Sci. Technol. 7, 91-95.

2. Bang, W., Hanson, D. J., and Drake, M. A. (2008) Effect of salts and sodium nitrite on growth and enterotoxin production of Staphylococcus aureus during the production of airdried fresh pork sausage. J. Food Prot. 71. 191-195.

3. Beales, N. (2004) Adaptation of microorganisms to cold temperatures, weak acid preservatives, low $\mathrm{pH}$, and osmotic stress: a review. Compr. Rev. Food Sci. F. 3, 1-20.

4. Cebrian, G., Sagarzazu, N., Pagan, R., Condon, S., and Manas, P. (2010) Development of stress resistance in Staphylococcus aureus after exposure to sublethal environmental conditions. Int. J. Food Microbiol. 140, 26-33.

5. CDC (Centers for Disease Control and Prevention) 2012. Foodborne outbreak online database (Food). Available from: http://wwwn.cdc.gov/foodborneoutbreaks/Default.aspx\#. Accessed Aug 6, 2012.

6. Chen, H. (2007) Use of linear, Weibull, and long-logistic functions to model pressure inactivation of seven foodborne pathogens in milk. Food Microbiol. 24, 197-204.

7. Dewaal, C. S., Hicks, G., Barlow, K., Alderton, L., and Vegosen, L. (2006) Foods associated with food-borne illness outbreaks from 1990 through 2003. Food Prot. Trends. 26, 466473.

8. Hill, C., Cotter, P. D., Sleator, R. D., and Gahan, C. G. M. (2002) Bacterial stress response in Listeria monocytogenes: jumping the hurdles imposed by minimal processing. Int. Dairy J. 12, 273-283.

9. Ingham, S. C., Engel, R. A., Fanslau, M. A., Schoeller, E. L., Searls, G., Buege, D. R., and Zhu, J. (2005) Fate of Staphylococcus aureus on vacuum-packaged ready-to-eat meat products stored at $21^{\circ}$ C. J. Food Prot. 68, 1911-1915.

10. Kim, A. J., Park, S. Y., Choi, J-W., Park, S. H., and Ha, S-D. (2006) Assessment of microbial contamination and nutrition of Kwangchun Shrimp Jeotgal (salt fermented shrimp). Korean Sci. Technol. 38, 121-127.

11. Koutsoumanis, K. P., Kendall, P. A., and Sofos, J. N. (2003) Effects of food processing-related stresses on acid tolerance of Listeria monocytogenes. Appl. Environ. Microb. 69, 75147516.

12. Lin, Y-D. and Chou, C-C. (2004) Effect of heat shock on thermal tolerance and susceptibility of Listeria monocytogenes to other environmental stresses. Food Microbiol. 21, 605-610.

13. Naber, C. K. (2009) Staphylococcus aureus bacteremia: epidemiology, pathophysiology, and management strategies. Clin. Infect. Dis. 48, 231-237.

14. San Martin, M. F., Barbosa-Canovas, G. V., and Swanson, B. G. (2002) Food processing by high hydrostatic pressure. Crit. Rev. Food Sci. 42, 627-645.

15. Schelin, J., Wallin-Carlquist, N., Cohn, M. T., Lindqvist, R., Barker, G. C., and Radstorm, P. (2011) The formation of Staphylococcus aureus enterotoxin in food environments and advances in risk assessment. Virulence. 2, 580-592.

16. Shadbolt, C., Ross, T., and McMeekin, T. A. (2001) Differentiation of the effects of lethal $\mathrm{pH}$ and water activity: food safety implications. Microbiology. 32, 99-102.

17. Skandamis, P. N., Stopforth, J. D., Yoon, Y., Kendall, P. A., and Sofos, J. N. (2009) Heat and acid tolerance response of Listeria monocytogenes as affected by sequential exposure to hurdles during growth. J. Food Prot. 72, 1412-1418.

18. USDHHS/FDA (U.S. Department of Health and Human Services/Food and Drug Administration) (2011). Food for human consumption. Sec. 114.3. Definition. Fed. Regist. 2, 242-243. 
19. Yoon, Y., Mukherjee, A., Belk, K. E., Scanga, J. A., Smith, G. C., and Sofos, J. N. (2009) Effect of tenderizers combined with organic acids on Escherichia coli $\mathrm{O} 157: \mathrm{H} 7$ thermal resistance in non-intact beef. Int. J. Food Microbiol. 133, 7885.

20. Yoon, Y., Mukherjee, A., Geornaras, I., Belk, K. E., Scanga,
J. A., Smith, G. C., and Sofos, J. N. (2011) Inactivation of Escherichia coli O157:H7 during cooking of non-intact beef treated with tenderization/marination and flavoring ingredients. Food Control. 22, 1859-1864.

$\overline{\text { (Received 2012.8.6/Revised 2012.10.17/Accepted 2012.10.26) }}$ 